報文

\title{
新規ラクチドコポリマーの合成と そのプロテアーゼによる分解性
}

\author{
白浜 博幸・水馬 潔志・安田 源 \\ 広島大学工学部第三類応用化学 ( 7739 東広島市鏡山 1 丁目 4-1)
}

Synthesis of New Lactide Copolymers and Their Degradability by Proteases

\author{
Hiroyuki Shirahama, Kiyoshi Mizuma, and Hajime Yasuda \\ Department of Applied Chemistry, Faculty of Engineering, Hiroshima University \\ (4-1, Kagamiyama 1-chome, Higashi-Hiroshima-shi, =739)
}

\begin{abstract}
For improving brittleness and biodegradability of poly ( L-lactide) [P(L-LA)], new lactide copolymers $[\mathrm{P}(\mathrm{L}-\mathrm{LA} /(R)-\mathrm{MOHEL})]$ composed of L-lactide ( $\mathrm{L}-\mathrm{LA})$ and $(R)-3^{-}$ methyl-4-oxa-6-hexanolide $\llbracket(R)$-MOHEL ; optical active new lactone $]$ were synthesized, and enzymatic degradation of the copolymers by proteases was examined. Lactides ( $L^{-}$and $D, L^{-}$isomers) and $(R)$-MOHEL homopolymers [P(L-LA), $\mathrm{P}(\mathrm{DL}-\mathrm{LA})$, and $\mathrm{P}[(R)-\mathrm{MOHEL}]]$ were used as reference samples.

Homo- and copolymerizations were carried out at $100^{\circ} \mathrm{C}$ for $4 \sim 8 \mathrm{~h}$ using $\mathrm{AlEt}_{3}-\mathrm{H}_{2} \mathrm{O}(1: 0.75)$ as the catalyst. Differential scanning calorimetry ( $\mathrm{SSC}$ ) indicated the polymers obtained [except homopolymers of DL-LA, $(R)$-MOHEL, and copolymers containing L-LA less than ca. 40 mol $\%$ ) to be crystalline. Brittleness was improved without much decrease in film melting temperature $\left(T_{\mathrm{m}}\right)$ compared to $\mathrm{P}(\mathrm{L}-\mathrm{LA})$, provided the copolymer contained $\mathrm{L}-\mathrm{LA}$ units at more than 60 mol\%.
\end{abstract}

Among the enzymes used [proteases (bromelain, pronase, and proteinase $\mathrm{K}$ ) and cholesterol esterase], proteinase $\mathrm{K}$ showed the highest degradability (i. e., substrate specificity) for lactide homopolymers (PLAs). The degradability of amorphous P(DL-LA) by each enzyme was greater than that of crystalline $\mathrm{P}(\mathrm{L}-\mathrm{LA})$. Proteinase $\mathrm{K}$ hardly degraded $\mathrm{P}[(R)-\mathrm{MOHEL}]$ at all.

In the case of copolymers containing L-LA units at more than 60 mol\%, the degradability by proteinase $\mathrm{K}$ increased with content of $(R)$-MOHEL, since the crystallinity (or $T_{\mathrm{m}}$ ) of the copolymers decreased with increase in $(R)$-MOHEL. Too much $(R)$-MOHEL decreased degradability very much $[$ e. g., $\mathrm{P}(\mathrm{L}-\mathrm{LA} /(R)-\mathrm{MOHEL}=29 / 71)]$.

Based on changes in molecular weight and thermal properties of (co)polymers before and after degradation by proteinase $\mathrm{K}$, enzymatic degradation apparently started from polymer (film) surfaces and occurred more easily in amorphous than crystalline parts.

Key Words : rondom copolymerization, lactide, optical active new lactone, enzymatic degradation, protease.

\section{1 緒 言}

プラスチック廃棄物による環境污染が地球的規模で進 行する中, 土中の微生物などにより分解可能な生分解性

連絡者 : 白浜博幸
高分子の開発はリサイクルと共に現在盛んに検討されて

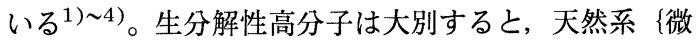
生物由来 (ポリエステルなど), 動植物由来 (多糖類, チキン・キトサンなど) \} と合成系 (脂肪族ポリエステ ルなど）に分類可能である。また，その主たる分解機構 から非酵素的で単純な加水分解による生体吸収性高分子 
と, (菌体外) 酵素により分解される環境分解性高分子 とに分類することも提唱されている5）。

ポリラクチド $[\mathrm{P}(\mathrm{LA})]$ 系高分子は非酵素分解型の代 表的な材料であり, その生体適合性から手術用縫合系や ドラッグデリバリーシステム (DDS) の担体 $\left.{ }^{1)} 4\right)$, そ して機械的強度に優れていることから近年は, 骨折用の 固定化材 $\left.{ }^{6)} 8\right)$ などのバイオマテリアル分野での利用が 活発となっている。しかしながら，ポリ（L-ラクチド） $\lceil\mathrm{P}(\mathrm{L}-\mathrm{LA})]$ は固くてもろいことから, その性質を改 良したり, また, 分解性をコントロールする目的で, $\mathrm{L}^{-}$

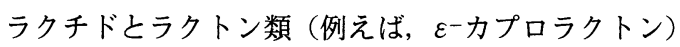
との共重合化などが行われている ${ }^{9) \sim 11)}$ 。ところで，㑐 リグリコール酸〔P(GA)]や $\mathrm{P}(\mathrm{LA})$ は上述のよう に，一般的には非酵素的加水分解しか受けないとされて いるが, 近年いくつかの酵素による分解も報告されてい る $^{12), 13)}$ 。本研究では, ラクチドとの共重合モノマーと

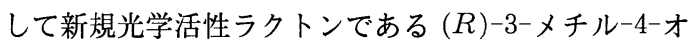
キサー6-ヘキサノリド〔( $R)-\mathrm{MOHEL}$ を用いた。 MOHEL は Table 1 に示した構造式からわかるように, 3ーヒドロキシ酪酸 (3 HB, このポリマー $[\mathrm{P}(3 \mathrm{HB})\}$ は微生物が産生する生分解性ポリエステルとして著名） とエチレングリコールから得られるラクトンに相当す る。従って, このユニットを導入しても $\mathrm{P}(\mathrm{LA})$ の生体 適合性を低下させることは少ないと思われる。また, MOHEL のホモポリマーP(MOHEL) は Table 2 に示 したように, ガラス転移温度 $\left(T_{\mathrm{g}}\right)$ が約 $-40^{\circ} \mathrm{C}$ の非晶 性高分子であり，このユニットをランダムにポリマー鎖 に導入すれば $\mathrm{P}(\mathrm{LA})$ に柔軟性を付与することが可能と 考えられる。MOHEL には光学異性体として $(R)$ 体, $(S)$ 体, ラセミ体が存在するが, 以前の我々の研究 ${ }^{14)}$ から $(R)$ 体のホモ及びコポリマーの生分解性が最大で あることが判明している。そこで本研究では, 柔軟性に
富みながら高融点を有し, かつ（酵素）分解性にも優れ たコポリマーを得る目的で, L-LA と $(R)$-MOHEL と のランダム共重合を行い, そのプロテアーゼによる分解 性をラクチドホモポリマー $\left\{\mathrm{P}(\mathrm{L}-\mathrm{LA})\right.$ 及び $\mathrm{P}\left(\mathrm{DL}^{-}\right.$ LA) [ポリ (DL-ラクチド)]\}と比較することにより検 討した。

\section{2 実 験}

\section{$2 \cdot 1$ 試 料}

$2 \cdot 1 \cdot 1$ ポリマーの合成

モノマーとしてラクチド [L-LA(Aldrich Chemical 社製), DL-LA[東京化成工業(株)製】 と新規光学活性

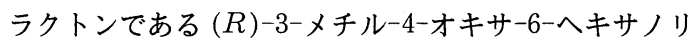
ド $[(R)-$ MOHEL, 高砂香料工業(株)より提供 $]$ とを用 いた。これらモノマーはトルエンに溶解後 $\mathrm{CaH}_{2}$ によ り乾燥した後, フラッシュ蒸留して精製した。各ホモポ リマー及び両者のコポリマーの代表的な合成条件を Table 1 に示す。重合はすべてアルゴン䨌囲気下トルエン 中, 触媒として $\mathrm{AlEt}_{3}-\mathrm{H}_{2} \mathrm{O}(1: 0.75)$ を用いて行っ た。これらポリマーはクロロホルムに溶解後メタノール 中に再沈殿 (2 回)することにより精製した。

\section{$2 \cdot 1 \cdot 2$ 酵 素}

酵素分解に用いたプロテアーゼは, ブロメリン [pineapple stem 由来, 活性 $5.29 \mathrm{IU}$ (国際単位) $/ \mathrm{mg}$, 和光純薬工業(株)製], プロナーゼ (nuclease free, Streptomyces griseus 由来, 活性 $12.4 \mathrm{IU} / \mathrm{mg}$, Calbiochem 社製) そしてプロティナーゼ K(Tritirachium album 由来, 活性 $20 \mathrm{IU} / \mathrm{mg}$, 和光純薬工業(株) 製〕を，また比較用のエステラーゼとしてコレステロー ルエステラーゼ (Pseudomonas sp. 由来, 活性 20 $\mathrm{IU} / \mathrm{mg}$, 和光純薬工業(株)製〕も用いた。これら各酵素 は市販品をそのまま使用した。

Table 1 Preparation of Some Aliphatic Polyesters Used ${ }^{\text {a) }}$ (Ar Atmosphere).

\begin{tabular}{lcccc}
\hline \multicolumn{1}{c}{ Polymer [molar ratio] } & $\begin{array}{c}\text { Catalyst }^{\mathrm{b})} \\
(\text { mol\%/monomer })\end{array}$ & $\begin{array}{c}\text { Time } \\
(\mathrm{h})\end{array}$ & $\frac{M_{\mathrm{n}}}{10^{3}}$ & $\frac{M_{\mathrm{w}}}{M_{\mathrm{n}}}$ \\
\hline $\mathrm{P}(\mathrm{L}-\mathrm{LA})$ & 1.0 & 4 & 23.6 & 1.46 \\
$\mathrm{P}(\mathrm{DL}-\mathrm{LA})$ & 1.0 & 8 & 18.4 & 1.20 \\
$\mathrm{P}[\mathrm{L}-\mathrm{LA} /(R)-\mathrm{MOHEL}][86 / 14]$ & 0.5 & 8 & 51.9 & 1.69 \\
$\mathrm{P}[\mathrm{L}-\mathrm{LA} /(R)-\mathrm{MOHEL}][43 / 57]$ & 0.5 & 8 & 26.2 & 1.58 \\
$\mathrm{P}[(R)-\mathrm{MOHEL}]$ & 1.0 & 8 & 49.4 & 1.73 \\
\hline
\end{tabular}

a) Polymerized at $100^{\circ} \mathrm{C}$, b) $\mathrm{AlEt}_{3}-\mathrm{H}_{2} \mathrm{O}(1: 0.75)$<smiles></smiles>

LA<smiles>CC1=CC(=O)OCCO1</smiles>

in toluene $100^{\circ} \mathrm{C} \times 4-8 \mathrm{~h}$
AlEt $_{3}-\mathrm{H}_{2} \mathrm{O}(1: 0.75)$

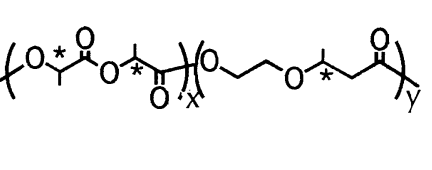

MOHEL 


\section{2 方 法}

\section{$2 \cdot 2 \cdot 1$ ポリマー諸物性の測定}

得られたポリマーの数平均分子量 $\left(M_{\mathrm{n}}\right)$ 及び分子量 分布 $\left(M_{\mathrm{w}} / M_{\mathrm{n}}\right)$ は東ソー(株) 製 GPC システム [カラ

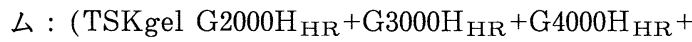
$\mathrm{G} 5000 \mathrm{H}_{\mathrm{HR}}$ ), カラム温度 $40^{\circ} \mathrm{C}$, 示差屈折率 $(\mathrm{RI})$ 検出 器]により, 溶離液としてクロロホルムを用い流速 1 $\mathrm{mL} / \mathrm{min}$ で, 標準ポリスチレンによる検量線から算出 した。

ポリマーの熱的特性 [ガラス転移温度 $\left(T_{\mathrm{g}}\right)$, 融点 $\left(T_{\mathrm{m}}\right)$ 及び融解熱 $\left.\left(\Delta H_{\mathrm{m}}\right)\right]$ はセイコー電子工業(株)製 の示差走査熱量計 (SSC 5100 DSC 22 C) を用いて昇温 速度 $10^{\circ} \mathrm{C} / \mathrm{min}$ で測定した。

コポリマーの組成比 [LA/MOHEL (モル比) ] は 270 $\mathrm{MHz}$ の核磁気共鳴装置 (JEOL EX-270) を用い, ${ }^{1} \mathrm{H}-$ NMR 測定により決定した。

\section{$2 \cdot 2 \cdot 2$ 酵素分解}

各酵素を所定の Good 緩衝液 $\{$ TES $[N$-トリス（ヒ ドロキシメチル) メチル-2-アミノエタンスルホン酸] : ブロメリンとコレステロールエステラーゼ用緩衝液 $(\mathrm{pH}$

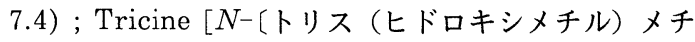
ル] グリシン] : プロナーゼとプロティナーゼ $\mathrm{K}$ 用 $(\mathrm{pH}$ $8.0)\}$ にサンプル管瓶中で溶解し, 分解温度 $\left(37^{\circ} \mathrm{C}\right)$ に 達するまで恒温槽中に放置した (約 $15 \mathrm{~min}) 。$ そして各 ポリマーをこれらの酵素分解液に投じて分解試験を開始 した。分解はサンプル管瓶を往復振とう (100 回 $/ \mathrm{min})$ しながら行った。なお，分解液の作製に用いた水は蒸留 ・イオン交換した純水を使用した。

分解試験においてポリマーサンプルは, MOHEL の ホモポリマーまたは MOHEL 含有量 $70 \mathrm{~mol} \%$ 以上の コポリマー（これらは柔らかすぎるためフィルム形成が 困難であり, 薄い板状塊として使用）を除いて, ソルベ ントキャスティング法により作製したフィルム (厚さ約 $100 \mu \mathrm{m})$ を用いた。各サンプルは網目約 $1 \times 1 \mathrm{~mm}$ のポ リエチレンシートメッシュ内に封じ込めた後, 上述した
各分解液に浸漬した。

分解性は, 各分解液に所定の時間浸漬したポリマーを 純水でよく洗浄し充分に乾燥させた後, 主にその重量変 化を測定することにより調べた。重量測定は各サンプル につき少なくとも 3 回行い, その平均值を採用した (平 均值からの最大誤差 $\pm 9.5 \%)$ 。また, 分解のメカニズ ムを検討する目的で, 酵素分解前後のポリマーの諸物性 変化も測定した。

\section{3 結果と考察}

\section{$3 \cdot 1$ ポリマーの諸物性}

Table 1 と 2 に得られた LA ホモポリマーならびに L-LA/ $(R)$-MOHEL コポリマーの諸物性を示す。Table 1 から数平均分子量 $\left(M_{\mathrm{n}}\right)$ が約 2 5 万で, 分子量 分布の比較的狭い $\left(M_{\mathrm{w}} / M_{\mathrm{n}}\right.$ 約 $\left.1.2 \sim 1.7\right)$ (コ)ポリマー が得られたことがわかる。

Table 2 には，これらポリマーの熱的特性を示す。LLA のホモポリマー $[\mathrm{P}(\mathrm{L}-\mathrm{LA})]$ は従来から報告されて いるように, $170^{\circ} \mathrm{C}$ 付近（本研究では $162^{\circ} \mathrm{C}$ ) に結晶ド メインの融解に由来する吸熱ピークを示した (DSC 測 定により判明)。ラセミ体であるポリ (DL-LA) $[\mathrm{P}(\mathrm{DL}-$ $\mathrm{LA})]$ は非晶性であり, $T_{\mathrm{g}}$ は $36^{\circ} \mathrm{C}$ であった。 $(R)-$ MOHEL のホモポリマー $[\mathrm{P}[(R)-\mathrm{MOHEL}]]$ も以前 報告しているように $T_{\mathrm{g}}$ が $-40^{\circ} \mathrm{C}$ の非晶性高分子であ る $^{14)}$ 。一方, L-LA/ $(R)-\mathrm{MOHEL}$ コポリマーの熱的特 定は, MOHEL ユニット導入量の増大に伴い $T_{\mathrm{g}}, T_{\mathrm{m}}$, $-\Delta H_{\mathrm{m}}$, 結晶化度はいずれも $\mathrm{P}(\mathrm{L}-\mathrm{LA})$ に比べ低下した が, 57 mol\% の MOHEL 含有量でも $100^{\circ} \mathrm{C}$ 近い $T_{\mathrm{m}}$ が 認められた。また, MOHEL ユニットが約 $60 \mathrm{~mol} \%$ 以 上では非晶性のコポリマーとなった。なお，ポリマーの 結晶化度は $100 \%$ 結晶 $\mathrm{P}(\mathrm{L}-\mathrm{LA})$ の $\Delta H_{\mathrm{m}} \lessdot-93.6 \mathrm{~J} / \mathrm{g}$ (DSC 测定と理論式から得られる誘導值) ${ }^{15)}$ と比較す ることにより決定した。

ところで, $\mathrm{P}(\mathrm{L}-\mathrm{LA})$ は前述したように機械的特性に 優れている反面, 固くてもろく, 融点と熱分解温度（約

Table 2 Thermal Properties ${ }^{\text {a) }}$ of Polyesters Used.

\begin{tabular}{|c|c|c|c|c|}
\hline $\begin{array}{c}\text { Polymer } \\
\text { (molar ratio) }\end{array}$ & $\begin{array}{l}T_{\mathrm{g}} \\
\left({ }^{\circ} \mathrm{C}\right)\end{array}$ & $\begin{array}{l}T_{\mathrm{m}} \\
\left({ }^{\circ} \mathrm{C}\right)\end{array}$ & $\begin{array}{c}-\Delta H_{\mathrm{m}} \\
(\mathrm{J} / \mathrm{g})\end{array}$ & $\begin{array}{c}\text { Crystallinity } \\
(\%)\end{array}$ \\
\hline $\mathrm{P}(\mathrm{DL}-\mathrm{LA})$ & 36.0 & - & - & - \\
\hline $\mathrm{P}(\mathrm{L}-\mathrm{LA})$ & 55.0 & 162.0 & 45.5 & 48.6 \\
\hline $\mathrm{P}[\mathrm{L}-\mathrm{LA} /(R)-\mathrm{MOHEL}=86 / 14]$ & 36.9 & 153.0 & 27.6 & 29.5 \\
\hline$=79 / 21]$ & 37.1 & 141.3 & 22.0 & 23.5 \\
\hline$=60 / 40]$ & -5.5 & 131.8 & 14.0 & 15.0 \\
\hline$=43 / 57]$ & -13.8 & 92.1 & 2.9 & 3.1 \\
\hline $\mathrm{P}[(R)-\mathrm{MOHEL}]$ & -40.0 & - & - & - \\
\hline
\end{tabular}

a) Determined by DSC measurement 


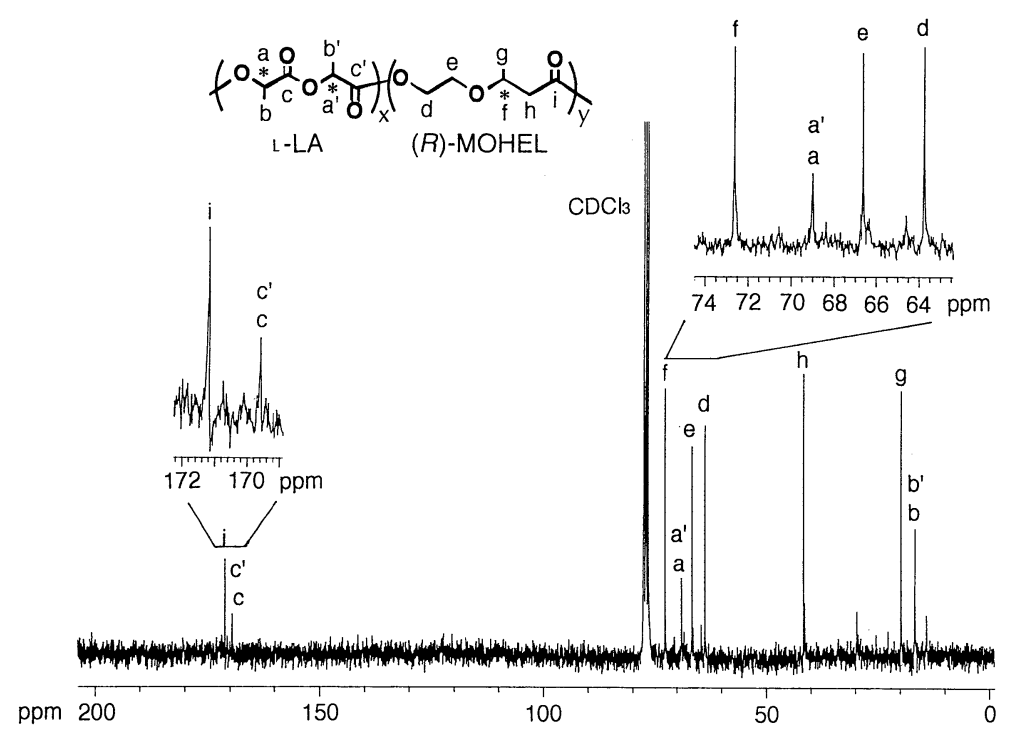

Fig. $1{ }^{13} \mathrm{C}-\mathrm{NMR}$ Spectrum of $\mathrm{P}(\mathrm{L}-\mathrm{LA} /(R)-\mathrm{MOHEL}=29 / 71)$.

$\left.200^{\circ} \mathrm{C}\right)$ が近いため, 加熱成型時の分子量及び強度低下 が懸念される。この問題の解決のために L-LA とラク

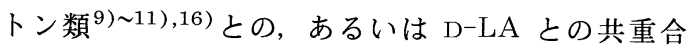

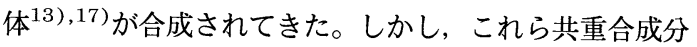
が 10〜30 mol\% 以上導入されると融点が観察されなく なり， P(L-LA) の結晶性ブロックが消失することが報 告されている ${ }^{17)}$ 。それらの結果に比べ，(R)-MOHEL との共重合化においては Table 2 からわかるように, MOHEL ユニットが $40 \mathrm{~mol} \%$ 存在しても $\mathrm{P}(\mathrm{L}-\mathrm{LA})$ の 融点をあまり低下させることなく，ポリマーに柔軟性を 付与することが可能であった。なお，得られたコポリ マーのミクロ構造については, $T_{\mathrm{g}}, T_{\mathrm{m}}, \Delta H_{\mathrm{m}}$ が $\mathrm{MO}$ HEL 量の増加と共に減少すること (Table 2) や, Fig. 1 に示す ${ }^{13} \mathrm{C}-\mathrm{NMR}$ スペクトルからわかるように, $-\mathrm{C}=\mathrm{O}$ 及び $-\mathrm{CH}_{2}$ (または $-\mathrm{CH}$ ) に由来するピークが細 かく分割していることから，比較的ランダム性に富んだ コポリマーが得られたものと考えられる。

\section{$3 \cdot 2$ 酵素分解性}

\section{$3 \cdot 2 \cdot 1$ ラクチドホモポリマーの分解性}

$\mathrm{P}(\mathrm{DL}-\mathrm{LA})$ の各種酵素による分解性（重量減少）を Fig. 2 に示す。用いたプロテアーゼのうち最大の分解 性を示したのはプロティナーゼ K 酵素であった。我々 の以前の研究 ${ }^{14)}$ から, 脂肪族のポリエーテルエステル やポリエステルカーボネートに対して, コレステロール エステラーゼは有効な分解性を示すことが判明したが, このエステラーゼ酵素を用いた分解性は酵素不在系の緩 衝液のみによる場合とほとんど差は認められなかった。

Fig. 3 には同じ酵素を用いた $\mathrm{P}(\mathrm{L}-\mathrm{LA})$ と $\mathrm{P}(\mathrm{DL}-$ LA) との分解性を比較した。図から P(L-LA) の場合

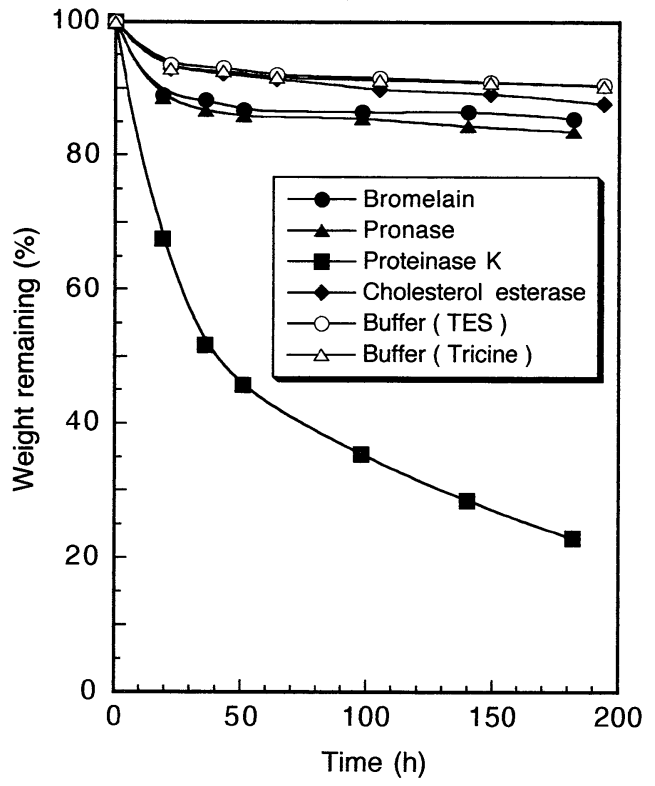

Fig. 2 Biodegradation of $\mathrm{P}(\mathrm{DL}-\mathrm{LA})$ with and without Enzymes at $37^{\circ} \mathrm{C}$.

もやはりプロティナーゼ K 酵素が最大の分解性を示す ことがわかる。また，いずれの酥素を用いても分解性は $\mathrm{P}(\mathrm{DL}-\mathrm{LA})>\mathrm{P}(\mathrm{L}-\mathrm{LA})$ となった。これは, 両者の結晶 性の差 $[\mathrm{P}(\mathrm{L}-\mathrm{LA})$ は(半)結晶性の, P(DL-LA) は非晶 性のポリマーであること〕に起因した, すなわち, 同種 のポリマーなら低結晶性の試料ほど分解性が大きいこと を反映した結果と考えられる。 


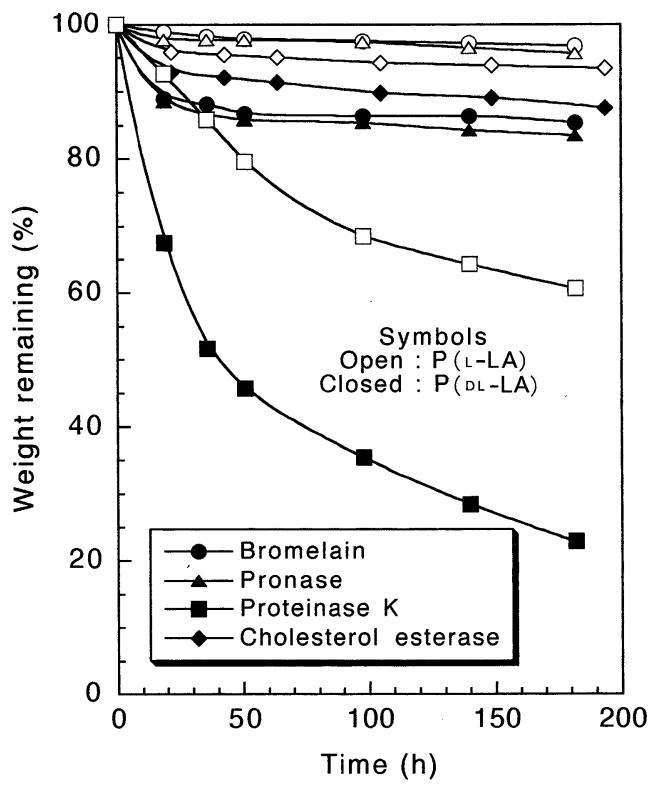

Fig. 3 Biodegradation of Lactide Homopolymers by Various Enzymes at $37^{\circ} \mathrm{C}$.

Williams ${ }^{12)}$ は同様のプロテアーゼ酵素を用いて P ( L -LA) の分解性を検討した結果, ブロメリンとプロナー ゼもプロティナーゼ K と同程度の分解性（重量減少） を示すことを報告している。しかしながら本研究では, ブロメリンとプロナーゼによる分解性は酵素不在の緩衝 液中よりは大きかったものの, プロティナーゼ K の場 合に比べ大きく低下している。我々はサンプルの形状と してフィルムを用いたが, 彼は比表面積の大きい微粒子 を用いており，このことがブロメリンとプロナーゼによ る分解性を本研究の場合よりも大きくした原因とも考え られる。脂肪族ポリエステルでは微粒子になるほど酵素 分解性が大きくなることが報告されている ${ }^{18)}$ 。一方, ブロメリンとプロナーゼはエキソキナーゼ型の, プロ ティナーゼ K はエンドキナーゼ型の挙動を示すとも言 われており ${ }^{12)}$, この違いが本研究におけるフィルムの 酵素分解性に差を生じさせたとも考えられる。しかしい ずれにせよ, 本研究の結果からは 3 種のプロテアーゼの うちプロティナーゼ $\mathrm{K}$ が $\mathrm{P}(\mathrm{LA})$ に対して基質特異性 が高いことしかわからない。これらプロテアーゼは恐ら くエステラーゼ活性をも有すると思われるが, プロティ ナーゼ K がなぜ（コレステロール）エステラーゼより も非常に大きな分解性を示すかなど, 分解の詳細につい ては基質特異性を含めてこれら酵素のさらなる研究が必 要であろう。

なお, 以後の実験においては最大の分解性を示したプ ロティナーゼ K を使用した。

Fig. 4 にはプロティナーゼ K による P(L-LA) の分

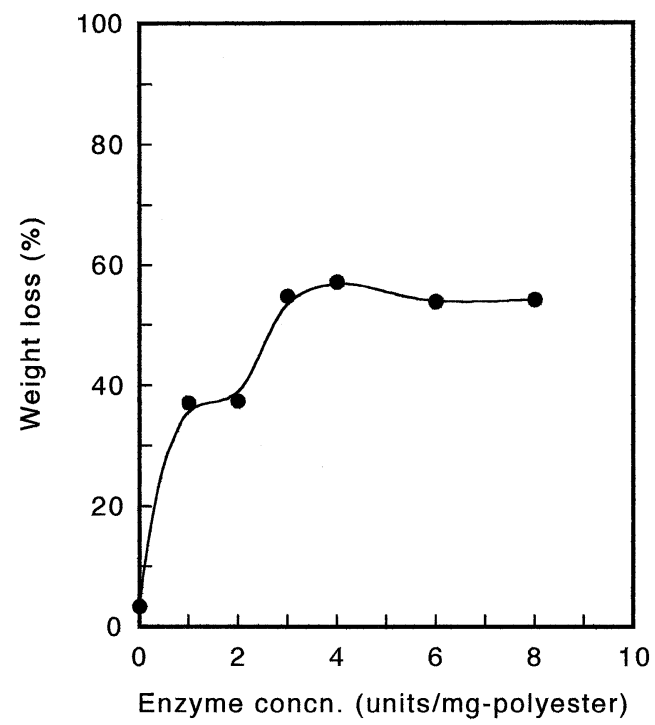

Fig. 4 Effect of Enzyme Concentration on Degradation (after ca. $185 \mathrm{~h}$ ) of $\mathrm{P}(\mathrm{L}-\mathrm{LA})$ by Proteinase $\mathrm{K}\left(37^{\circ} \mathrm{C}, \mathrm{pH} 8\right)$.

解性（約 $185 \mathrm{~h}$ 後）に及ぼす酵素濃度の影響について示 す。図からわかるように分解は酵素濃度と共に増大し, ステップを経てプラトーに達した。このように酵素濃度 増大により分解がプラトーに達する現象は脂肪族ポリエ

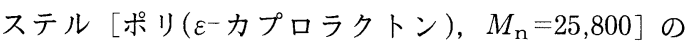
Rhizopus delemar リパーゼによる分解においても観 察されている ${ }^{19)}$ 。ところで, ポリエステルのような水 に不溶性の高分子が酵素により分解される場合, 酵素が それら高分子に吸着することが以後の酵素 (分解) 反応 には効率が良いとされており, 実際にリパーゼ類などで そのような吸着部位（あるいは基質界面認識部位）が存 在することが報告されている20)。Fig. 4 で認められた ような, 酵素濃度による重量変化 (分解) にステップが 存在するかどうかは, 用いるポリマーや酵素の種類など に依存することも予想される。この現象の可能な解釈と しては, 酵素分子のポリマー表面への緩やかな（単分子 層）吸着飽和（最初のプラトーまで）から, より密な単 分子層吸着飽和への変化 (ステップ以降) が考えられ る。ステップ以降 (3 units 以上) で分解が再びプラ トーに達するのは, この濃度領域では酵素分子の多層吸 着や吸着配向の変化が起こり, ポリマー表面の分解部位 （エステル結合）に酵素の活性部位が有効に作用できな くなるためと思われる。

$3 \cdot 2 \cdot 2$ コポリマーの分解性と分解のメカニズム

プロティナーゼ K によるコポリマーの分解性を Fig. 5 に示す。なお，この図には比較のため各ホモポリマー の分解性についても示した。ホモポリマーの分解性は, 


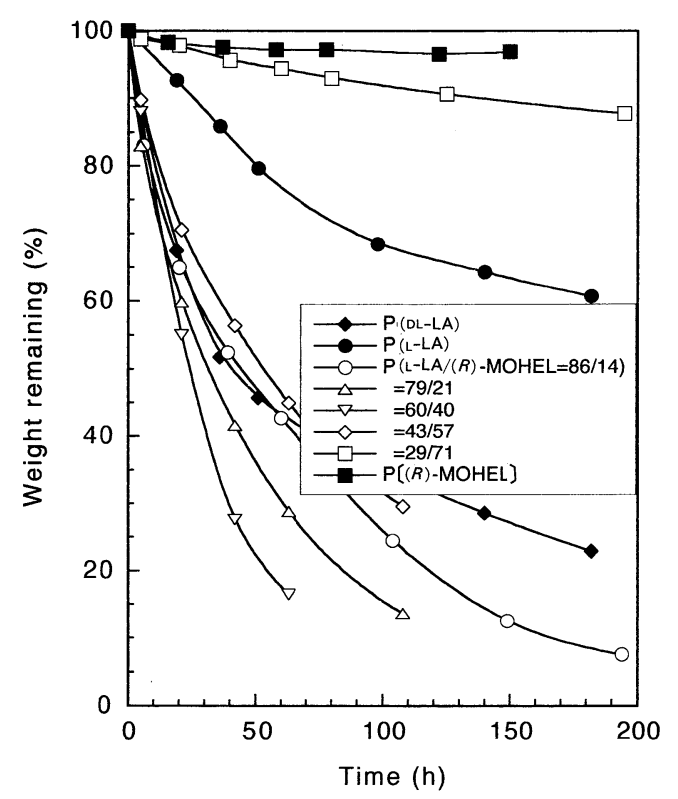

Fig. 5 Enzymatic Degradation of Lactide Homoand Copolymers by Proteinase $\mathrm{K}\left(37^{\circ} \mathrm{C}\right.$, pH 8).

$\mathrm{P}(\mathrm{DL}-\mathrm{LA})>\mathrm{P}(\mathrm{L}-\mathrm{LA})>\mathrm{P}(R)-\mathrm{MOHEL}$ の順となり, 本酵素は $\mathrm{P} 〔(R)-\mathrm{MOHEL}]$ に対しては分解性（基質特 異性）をほとんど示さないことが判明した。一方，コポ リマーの分解性は図からわかるように, L-LA/ $(R)-$ MOHEL のモル組成比が 86/14 から 60/40 までは, MOHEL ユニットの増加とともに分解性は P ( L-LA) に比べ大きく増大した [これらコポリマーの分解性は最 終的には非晶性の $\mathrm{P}(\mathrm{DL}-\mathrm{LA})$ よりも大となった れは後述するように，コポリマーの結晶性（あるいは融 点）が MOHEL ユニットの増加に伴い減少するからと 考えられる。しかし，これ以上このユニットを増加させ ても分解性は逆に低下する傾向を示した。いずれにせ よ, 組成比が約 $40 / 60$ まではコポリマーの分解性は $\mathrm{P}(\dot{\mathrm{L}}$ 一LA) に比べかなり改善された。

これまでの結果より, プロティナーゼ K による分解 性は, ポリマーの物性（特に熱的特性）に大きく依存す ることがわかった。そこで本研究では, L-LA/ $(R)-$ MOHEL コポリマーの結晶化度とその酵素分解性（約 $60 \mathrm{~h}$ 後の重量損失) を L-LA 含量の関数として検討し た (Fig. 6)。図からわかるように, LA 含量約 $60 \mathrm{~mol}$ $\%$ 以上では結晶化度の上昇に伴いポリマーの分解性は 低下した。一方, LA 含量 $60 \mathrm{~mol} \%$ 以下のコポリマー (43 mol\% 以下では非晶性) では逆の傾向を示した [Fig. 5 からわかるように, L-LA/ $(R)-\mathrm{MOHEL}=$ 29/71 のコポリマーでは $\mathrm{P}[(R)-\mathrm{MOHEL}]$ と同様に分 解性が非常に低下した]。これは, プロティナーゼ $\mathrm{K}$ 酵

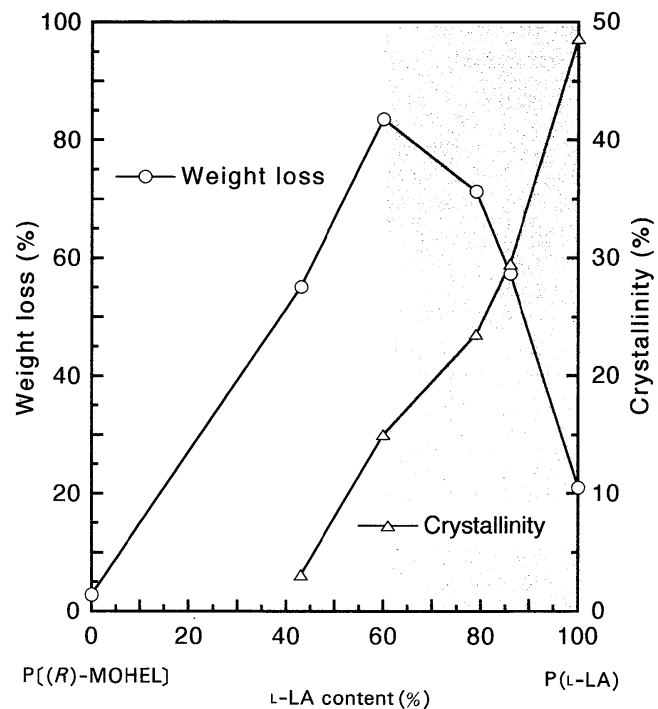

Fig. 6 Relation between Biodegradability (at $c a$. $60 \mathrm{~h}$ ) by Proteinase $\mathrm{K}$ and Crystallinity of L-LA/ $(R)$-MOHEL Copolymers as a Function of L-LA Content.

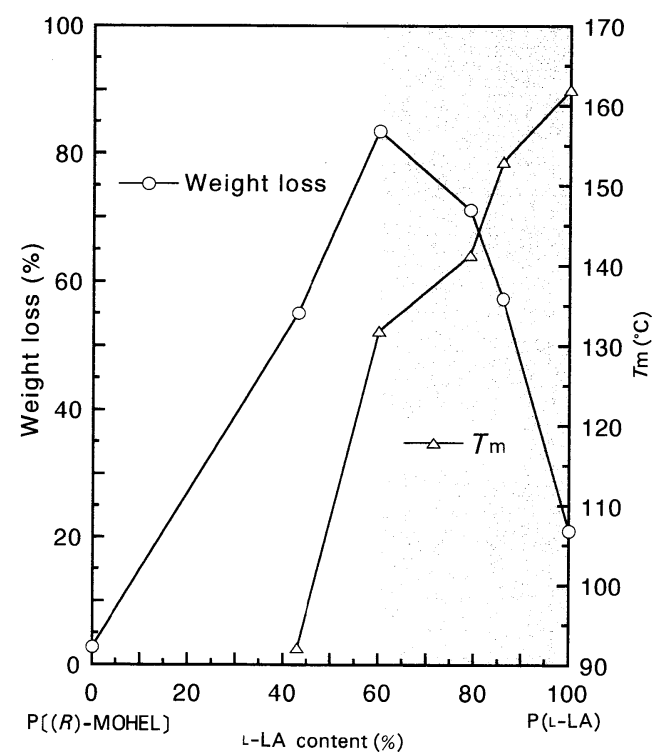

Fig. 7 Relation between Biodegradability (at $c a$. $60 \mathrm{~h}$ ) by Proteinase $\mathrm{K}$ and Melting Point $\left(T_{\mathrm{m}}\right)$ of $\mathrm{L}-\mathrm{LA} /(R)-\mathrm{MOHEL}$ Copolymers as a Function of $\mathrm{L}-\mathrm{LA}$ Content.

素が LA ユニットに対して基質特異性が高いことか ら，ある程度 LA 部位が存在しないと本酵素が作用し ないことと, 逆に L-LA ユニット量が多くなりすぎる とコポリマーの結晶化度が増大し分解性が低下するこ と, とのバランスから生じた結果と考えられる。また, 
Table 3 Changes in Some Properties of Polyesters before and after Degradation by Proteinase K.

\begin{tabular}{|c|c|c|c|c|c|c|c|c|c|}
\hline Polymer & $\begin{array}{l}\text { Time } \\
\text { (h) }\end{array}$ & $\begin{array}{l}\text { Weight } \\
\text { loss (\%) }\end{array}$ & $\begin{array}{l}\left.\text { Composition }^{a}\right) \\
\text { (molar ratio) }\end{array}$ & $\frac{M_{\mathrm{n}}^{\mathrm{b})}}{10^{3}}$ & $\frac{M_{\mathrm{w}}^{\mathrm{b})}}{M_{\mathrm{n}}}$ & $\begin{array}{l}\left.T_{\mathrm{g}} \mathrm{c}\right) \\
\left({ }^{\circ} \mathrm{C}\right)\end{array}$ & $\begin{array}{l}\left.T_{\mathrm{m}} \mathrm{c}\right) \\
\left({ }^{\circ} \mathrm{C}\right)\end{array}$ & $\begin{array}{l}-\Delta H_{\mathrm{m}}^{\mathrm{c})} \\
(\mathrm{J} / \mathrm{g})\end{array}$ & $\begin{array}{c}\left.\text { Crystallinity }{ }^{\mathrm{d}}\right) \\
(\%)\end{array}$ \\
\hline \multirow{2}{*}{$\mathrm{P}(\mathrm{DL}-\mathrm{LA})$} & 0 & 0 & - & 18.4 & 1.20 & 36.0 & - & - & - \\
\hline & 182 & 77.1 & - & 16.0 & 1.20 & - & - & - & - \\
\hline \multirow[t]{2}{*}{$P(L-L A)$} & 0 & 0 & - & 23.6 & 1.46 & 55.0 & $162.0^{\circ}$ & 45.5 & 48.6 \\
\hline & 182 & 39.3 & - & 23.0 & 1.44 & 58.9 & 162.4 & 48.7 & 52.0 \\
\hline \multirow{2}{*}{$\begin{array}{l}\mathrm{P}[\mathrm{L}-\mathrm{LA} /(R)-\mathrm{MOHEL} \\
=86 / 14]\end{array}$} & 0 & 0 & $86 / 14$ & 51.9 & 1.69 & 36.9 & 153.0 & 27.6 & 29.5 \\
\hline & 262 & 96.4 & $86 / 14$ & 46.9 & 1.51 & 40.1 & 153.6 & 30.4 & 32.5 \\
\hline \multirow{2}{*}{$\begin{array}{l}\mathrm{P}[\mathrm{L}-\mathrm{LA} /(R)-\mathrm{MOHEL} \\
=79 / 21]\end{array}$} & 0 & 0 & $79 / 21$ & 45.5 & 1.76 & 37.1 & 141.3 & 22.0 & 23.5 \\
\hline & 108 & 86.4 & $80 / 20$ & 45.3 & 1.73 & 36.6 & 143.0 & 24.3 & 26.0 \\
\hline \multirow{2}{*}{$\begin{array}{l}\mathrm{P}[\mathrm{L}-\mathrm{LA} /(R)-\mathrm{MOHEL} \\
=60 / 40]\end{array}$} & 0 & 0 & $60 / 40$ & 33.3 & 2.04 & -5.5 & 131.8 & 14.0 & 15.0 \\
\hline & 63 & 83.5 & $60 / 40$ & 31.7 & 1.80 & -6.4 & 131.8 & 17.0 & 18.2 \\
\hline \multirow{2}{*}{$\begin{array}{l}\mathrm{P}[\mathrm{L}-\mathrm{LA} /(R)-\mathrm{MOHEL} \\
=43 / 57\rceil\end{array}$} & 0 & 0 & $43 / 57$ & 26.2 & 1.58 & -13.8 & 92.1 & 2.9 & 3.1 \\
\hline & 108 & 70.5 & $48 / 52$ & 27.2 & 1.55 & -14.9 & 88.7 & 7.0 & 7.5 \\
\hline \multirow[t]{2}{*}{$\mathrm{P}[(R)-\mathrm{MOHEL}]$} & 0 & 0 & - & 49.4 & 1.73 & -40.0 & - & - & - \\
\hline & 304 & 4.2 & - & 43.6 & 1.74 & - & - & - & - \\
\hline
\end{tabular}

a), b), c) : Determined by ${ }^{1} \mathrm{H}-\mathrm{NMR}, \mathrm{GPC}$, and DSC measurements, respectively.

d) : Obtained from $\Delta H_{\mathrm{m}}$ values.

Table 4 Changes in Some Properties of $\mathrm{P}[\mathrm{L}-\mathrm{LA} /(R)-\mathrm{MOHEL}=86 / 14]$ as a Function of Degradation Time (Degradation by Proteinase K).

\begin{tabular}{rcccccccc}
\hline $\begin{array}{c}\text { Time } \\
(\mathrm{h})\end{array}$ & $\begin{array}{c}\text { Weight } \\
\text { loss }(\%)\end{array}$ & $\begin{array}{c}\left.M_{\mathrm{n}}{ }^{\mathrm{a}}\right) \\
10^{3}\end{array}$ & $\frac{\left.M_{\mathrm{w}}{ }^{\mathrm{a}}\right)}{M_{\mathrm{n}}}$ & $\begin{array}{c}\left.\text { LA/MOHEL }{ }^{\mathrm{b}}\right) \\
(\text { molar ratio })\end{array}$ & $\begin{array}{c}T_{\mathrm{g}}{ }^{\mathrm{c})} \\
\left({ }^{\circ} \mathrm{C}\right)\end{array}$ & $\begin{array}{c}\left.T_{\mathrm{m}}{ }^{\mathrm{c}}\right) \\
\left({ }^{\circ} \mathrm{C}\right)\end{array}$ & $\begin{array}{c}\left.-\Delta H_{\mathrm{m}}{ }^{\mathrm{c}}\right) \\
(\mathrm{J} / \mathrm{g})\end{array}$ & $\begin{array}{c}\text { Crystallinity } \\
(\%)\end{array}$ \\
\hline 0 & 0 & 51.9 & 1.69 & $86 / 14$ & 36.9 & 153.0 & 27.6 & 29.5 \\
5 & 19.8 & 50.2 & 1.65 & - & 43.8 & 153.0 & 28.5 & 30.4 \\
24 & 37.6 & 46.9 & 1.58 & - & 41.8 & 153.0 & 29.7 & 31.7 \\
144 & 95.0 & - & - & - & 40.1 & 153.6 & 30.4 & 32.5 \\
262 & 96.4 & 46.9 & 1.51 & $86 / 14$ & - & - & - & - \\
\hline
\end{tabular}

a), b), c) : Determined by GPC, ${ }^{1} \mathrm{H}-\mathrm{NMR}$, DSC measurements, respectively.

d) : Obtained from $\Delta H_{\mathrm{m}}$ values.

分解性に及ぼす融点 $\left(T_{\mathrm{m}}\right)$ の影響についても, L-LA 含 量 $60 \mathrm{~mol} \%$ 以上では $T_{\mathrm{m}}$ の上昇と共に重量損失（分解 性）が低下することが判明した (Fig. 7)。

続いてこれらポリマーの分解メカニズムを解析する目 的で, プロティナーゼ $\mathrm{K}$ 酵素による分解前後の各ポリ マーの諸物性の変化を調べ Table 3 に示した。P $[(R)$ MOHEL] を除いてポリマーの重量損失（分解性）は かなり認められるのに対して, 分子量 $\left(M_{\mathrm{n}}\right)$ 及びその 分布 $\left(M_{\mathrm{w}} / M_{\mathrm{n}}\right)$ そしてコポリマー組成は分解前後でわ ずかの変化しか観察されなかった。これらのことから,

酵素分解は主としてポリマーの表面から内部に向けて起 こり, コポリマー組成も全体的に均一となっていること が示唆された。一方, 熱的特性の変化をみると, 結晶性
の低い $\mathrm{P}[\mathrm{L}-\mathrm{LA} /(R)-\mathrm{MOHEL}=43 / 57]$ 及び非晶性の ポリマーを除いて, 融点 $\left(T_{\mathrm{m}}\right)$ は分解後に上昇した。 さらに, 融解熱 $\left(\Delta H_{\mathrm{m}}\right)$, 換言すれば結晶化度の值はい ずれの結晶性ポリマーにおいても分解後に増大している ことがわかる。また Table 4 には $\mathrm{P}[\mathrm{L}-\mathrm{LA} /(R)-\mathrm{MO}-$ $\mathrm{HEL}=86 / 14]$ コポリマンについて, 熱的特性の分解時 間 (分解率) による変化を示した。この表から分解の進 行と共に結晶化度の值は上昇していることがわかる。以 上の結果より, 結晶性ポリマーの場合, 酵素分解はポリ マーの非晶質部からの方が起こりやすいことが判明し た。しかしながら, ポリマー分解に伴う結晶化度 (融解 熱）の值の上昇はそれほど大きくならないことから, 結 晶部位の分解も並行してある程度起こっているものと考 
えられる。

\section{4 総 括}

本研究では, ポリ (L-ラクチド) $[\mathrm{P}(\mathrm{L}-\mathrm{LA})]$ の固く てもろい性質ならびにその生分解性を改良する目的で, L-LA と新規光学活性ラクトン $(R)-\mathrm{MOHEL}$ とのコ ポリマー $[\mathrm{P}[\mathrm{L}-\mathrm{LA} /(R)-\mathrm{MOHEL}]]$ を合成し，その 酥素分解性を主としてプロテアーゼを用いて検討した。 比較用のポリマーとして LA ( $\mathrm{L}^{-}$及び $\mathrm{D}, \mathrm{L}^{-}$体) と (R)-MOHEL のホモポリマーを用いた。

重合触媒として $\mathrm{AlEt}_{3}-\mathrm{H}_{2} \mathrm{O}(1: 0.75)$ を用いて 100 ${ }^{\circ} \mathrm{C}$ で 4 $8 \mathrm{~h}$ 反応を行った結果, 数平均分子量 $\left(M_{\mathrm{n}}\right)$ で 約 2 5 万の比較的分子量分布 $\left(M_{\mathrm{w}} / M_{\mathrm{n}}\right)$ の狭いホモ及 びコポリマーが得られた。得られたポリマーのうち, DL-LA と $(R)$-MOHEL のホモポリマーそして L-LA 含量約 $40 \mathrm{~mol} \%$ 以下のコポリマーは非晶性であること が DSC 測定結果により確認された。また, ${ }^{13} \mathrm{C}-\mathrm{NMR}$ の測定結果よりコポリマーはランダム性が強いことが明 らかとなった。コポリマーは MOHEL ユニット導入量 が $40 \mathrm{~mol} \%$ でも融点 $\left(T_{\mathrm{m}}\right)$ が約 $132^{\circ} \mathrm{C}$ あり, $\mathrm{P}\left(\mathrm{L}^{-}\right.$ LA) の $T_{\mathrm{m}}$ をそれほど低下させずにポリマー（フィル ム）に柔軟性を付与することが可能であった。

ラクチドホモポリマー [P(LA)] のプロテアーゼによ

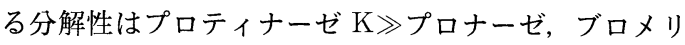
ンとなり, 特にプロティナーゼ K 酵素が $\mathrm{P}(\mathrm{L}-\mathrm{LA})$ に 対して高い基質特異性を示した。比較用として用いたコ レステロールエステラーゼによる分解はあまり認められ なかった。また,いずれの酵素を用いても非晶性の P(DL -LA) の分解性が大であった。(R)-MOHEL ホモポリ マーに対してはプロティナーゼ $\mathrm{K}$ 酵素は分解性（基質 特異性）をほとんど示さなかった。

コポリマーのプロティナーゼ K 酵素による分解は, L-LA 含量が $60 \mathrm{~mol} \%$ 以上では $(R)-\mathrm{MOHEL}$ ユニッ 卜量の増加と共に増大した。これは, コポリマーの結晶 化度 (あるいは $T_{\mathrm{m}}$ ) が MOHEL 量の増大に伴い減少す るからであると考察された。一方, L-LA 含量が低下し MOHEL 量が増大すると本酵素の基質特異性が減少す る結果, 例えば $\mathrm{L}-\mathrm{LA} /(R)-\mathrm{MOHEL}=29 / 71$ のコポリ マーでは分解性が $\mathrm{P}[(R)-\mathrm{MOHEL}]$ と同程度まで低下 した。

各ポリマーのプロティナーゼ K 酵素による分解前後 の $M_{\mathrm{n}}$ (又は $\left.M_{\mathrm{w}} / M_{\mathrm{n}}\right)$ の変化から, 分解はポリマー
(フィルム)の表面から起こっていることが示された。ま た, 分解前後における結晶性ポリマーの熱的特性 $\left(T_{\mathrm{m}}\right.$, $\Delta H_{\mathrm{m}}$, 結晶化度) の変化から, 酵素分解はポリマーの非 晶質部位の方が起こりやすいことも判明した。

以上の結果から， $(R)$-MOHEL を共重合することに より $\mathrm{P}(\mathrm{L}-\mathrm{LA})$ の（固くてもろい）性質や生分解性を 大きく改善した新規ラクチドコポリマーが得られること が明らかとなった。

(受付: 1995 年 11 月 28 日, 受理 : 1996 年 2 月 9 日)

\section{文 献}

1）土肥義治編著，“生分解性高分子材料”工業調查会 (1990).

2）筏 義人編, “生分解性高分子” 高分子刊行会 (1994).

3) Y. Doi, K. Fukuda (eds.), "Biodegradable Plastics and Polymers", Elsevier, Amsterdam (1994).

4）生分解性プラスチック研究会編, “生分解性プラスチッ クハンドブック”, エヌ・ティー・エス (1995).

5）望月政嗣，“生分解性术リマーのはなし”, 日刊工業新聞 社 (1995) p. 27.

6) A. Majora, S. Vainionää, A. Rokkanen, H.-M. Mikkola, P. Törmälä, J. Mater. Sci. Mater. Med., 3, 43 (1992).

7) M.J. Manninen, J. Mater. Sci., Mater. Med., 4, 179 (1993).

8) P. Ylinen, J. Mater. Sci. Mater. Med., 5, 522 (1994).

9) A.S. Sawhney, J.A. Hubbell, J. Biomed. Mater. Res., 24, 1397 (1990).

10) X. Zhang, U.P. Wyss, D. Pichora, M.F.A. Goosen, J. Macromol. Sci. Pure Appl. Chem., A 30 (12), 933 (1993).

11) M. Bero, G. Adamus, J. Kasperczyk, H. Janeczek, Polym. Bull., 31, 9 (1993).

12) D.F. Williams, Eng. Med., 10 (1), 5 (1981).

13) M.S. Reeve, S.P. McCarthy, M.J. Downey, R.A. Gross, Macromolecules, 27, 825 (1994).

14）白洪博幸, 水馬潔志, 川口佳秀, 塩見直紀, 安田 源, 高分子論文集, 50, 821 (1991).

15) E.W. Fisher, H.J. Sterzel, G. Wegner, Kolloid Z.Z. Polym., 251, 980 (1973).

16) 小島圭介, 白浜博幸, 安田 源, 第 43 回高分子討論会 予稿集 (福岡市), 43 (11), 3998 (1994).

17) 水馬潔志, 広島大学大学院工学研究科修士論文 (1994).

18) Y. Tokiwa, T. Suzuki, Agric. Biol. Chem., 42, 1071 (1978).

19）白浜博幸, 安田 源, ポリマーダイジェスト， 44,2 (1992).

20) K. Shirai, N. Matsuoka, Y. Saito, S. Yoshida, Biochim. Biophys. Acta, 795, 1 (1984). 


\section{[報文] 新規ラクヂドコポリマーの合成と そのプロテアーゼによる分解性 \\ 白浜博幸 - 水馬潔志 - 安田源 広島大学 工学部 第三類応用化学 \\ （开739 東広島市鏡山1-4-1）}

ポリ（Lーラクチド）［P（L-L A ）］の固くてもろい性質と生分解性を改善する目的で, L-ラクチド ( $\mathrm{L}-\mathrm{L}$

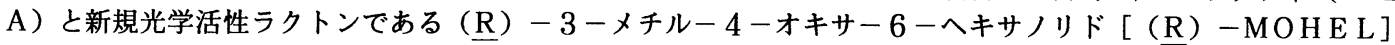
とから成る新しいラクチドコポリマー $[\mathrm{P}(\mathrm{L}-\mathrm{L} \mathrm{A} /(\underline{\mathrm{R}})-\mathrm{MOHEL})]$ を合成し，それらのプロテアーゼ による醉素分解性を検討した。比較用としてラクチド (L一及びD, L一体) と（R）-MOHE Lのホモポリマー $[\mathrm{P}(\mathrm{L}-\mathrm{LA}), \mathrm{P}(\mathrm{DL}-\mathrm{LA}), \mathrm{P}[(\mathrm{R})-\mathrm{MOHEL})]$ を用いた。

単独及び共重合は触媒に $\mathrm{A}_{1} \mathrm{E} \mathrm{t}_{3}-\mathrm{H}_{2} \mathrm{O}(1: 0.75)$ を用いて $100{ }^{\circ} \mathrm{C} て ゙ 4 \sim 8 \mathrm{~h}$ 行った。示差走查熱 量測定（D S C ）から, DL- L A ，（R）-MOHE L，そしてL-L A 含量約 $40 \mathrm{mo} 1 \%$ 以下のコポリマーを 除いて，得られたポリマーは結晶性であることがわかった。コポリマーのL-L A ユニット含量が約 $60 \mathrm{~mol} \%$ 以上であれば, ポリマーフィルムの骶解温度 $\left(\mathrm{T}_{\mathrm{m}}\right)$ を $\mathrm{P}(\mathrm{L}-\mathrm{L} \mathrm{A})$ に比べそれほど低下させることなく，もろさ を改善することが可能であった。

用いた䤃素 [プロテアーゼ（ブロメリン，プロナーゼ，プロティナーゼK） とコレステロールエステラーゼ] のうち, プロティナーゼKがラクチドホモポリマー（P L A) に対して最も高い分解性（換言すれば，基質特異性) を示した。非晶質 P (DL- L A ) の各䣼素による分解性は結晶性 P (L-L A ) のそれよりも大きかった。しかし， $\mathrm{P}[(\underline{\mathrm{R}})-\mathrm{MOHEL})$ はプロティナーゼK䣼素によりほとんど分解されなかった。

$\mathrm{L}$ - L A 含量約 $60 \mathrm{mo}$ 1\%以上のコポリマーにおいては, プロティナーゼK醉素による分解性は $(\mathrm{R})-\mathrm{MO}$ $\mathrm{HE} L$ 含量の增加に伴い增大した。これは, コポリマーの結晶化度（または $\mathrm{T}_{\mathrm{m}}$ ）が $(\underline{\mathrm{R}})-\mathrm{MOHE}$ L の增加之

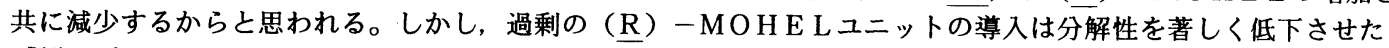

[例えば, P ( L-L A / (R) - MOHE L = 29/71)]。

プロティナーゼKによる分解前後の（コ）ポリマーの分子量及び熱的特性の変化から, 醉素分解はポリマー（フ イルム）の表面から開始され，そして結晶部よりも非晶質部の方が起こりやすいことが明示された。

（連絡者: 白浜博幸）Vo1. 45 , No. 5,459 (1996).

\section{[報文] 2-(ペルフルオロオタチル)エタノ一ル上 ジシクロペンタジェン付加物のヒドロキジ化 抢よびそのアミノアルキド樹脂叙料人の底用 \\ 吉 村 彦二 \\ アムコエンタープライズ株式会社（テ150 東京都渋谷区渋谷4-3-27）}

ポリマーへのペルフルオロオクチル基の導入と, その塗料組成物への応用について, 次の順序で研究した。 1) 8 (9)-[2-(ペルフルオロオクチル)エトキシ]トリシクロ[5.2.1.0 20-6]デカ-3，4-エポキシドのジオキ サン溶媒中での塩酸との反応, 触媒 $\mathrm{B} \mathrm{F}_{3}$ 存在下での過剩のメタノール中での反応によって, 高収率, 高純度に 各々相到するヒドロキシ化合物が得られた。

2) 前記ヒドロキシ化合物とイソホロンジイソシアナート等モル反応により，2種類の変性剤を合成した。

3）変性剤の短油長アルキド樹脂への添加, 加熱でアルキド樹脂のヒドロキシ残基とイソシアナートの反応は完結 した。

4) ペルフルオロオクチル変性アルキド樹脂とブチル化メラミン樹脂からアミノアルキド樹脂塗料組成物を調整し 造膜, 焼付処理して, 接触角および動的粘弾性を測定した。 結果は次の様になった。

(A) 未変性アミノアルキド塗膜の接触角が $80 \sim 85$ 度に対し, ペルフルオロオクチル約 $2 \mathrm{w} \mathrm{t}$. \%含有の変性 アミノアルキド膜でも, 110 度程であった。

(B) 変性アミノアルキド塗膜の $\mathrm{T} g$ は, 架橋密度の減少にもかかわらず, 上昇した。変性剤はペルフルオロオク チル基と脂環構造のつり合いが良く，優れたものであった。

（連絡者：吉村彦二） Vo1. 45, No. 5, 467 (1996). 